кандидат педагогічних наук, доцент

(Львівський національний університет імені Івана Франка) mariya.kozolup@lnu.edu.ua

ORCID: $0000-0002-5892-6696$

\title{
АКАДЕМІЧНА КОМУНІКАТИВНА ПІДГОТОВКА СТУДЕНТІВ У ВНЗ: КОМПЕТЕНТНІСНИЙ ПІДХІД
}

Стаття присвячена вивченню шляхів застосування компетентнісного підходу до академічної комунікативної підготовки майбутніх фахівців природничої галузі у ВНЗ. У ході дослідження з'ясовано сутність та запропоновано визначення поняття "академічна комунікативна компетентність". Розглянуто структуру ијєї компетентності, яка інтегрує компоненти ключових, галузевих та спеціально-предметних компетентностей і вміщує три групи компетенцій: когнітивні, власнекомунікативні та адаптивні. Обгрунтовано ефективність використання компетентнісного підходу до дисииплінарно-академічної комунікативної підготовки студентів природничих спеціальностей на підставі вивчення досвіду американської системи вищої освіти.

Ключові слова: компетентнісний підхід, компетенція, компетентність, комунікативна компетентність, академічна комунікативна компетентність.

Такі реалії сьогодення, як формування глобального наукового простору, становлення єдиних норм світової академічної культури, інтернаціоналізація науково-фахових дискурсів ставлять нові вимоги щодо комплексної підготовки майбутніх фахівців-науковців, зокрема у галузі природничих наук, де глобалізаційно-об'єднавчі процеси особливо відчутні. Сучасна наука вийшла за межі національних кордонів, а відтак формування цілісної особистості майбутнього ученого, готового реалізувати свій потенціал у співпраці з колегами з будь-якого регіону планети, передбачає не лише опанування вузькопрофесійними знаннями, уміннями i навичками, але й розвиток комунікативних та соціоадаптивних компетенцій, що $€$ інтегральними компонентами комплексної професійної компетентності сучасного фахівця.

Комептентнісний підхід - один із ефективних методологічних підходів, спрямованих на підготовку майбутніх фахівців. На думку В. Лозової, він передбачає "аксіологічні, мотиваційні, рефлексійні, когнітивні, операційно-технологічні та інші результати навчання, які відображають розширення не тільки знань, умінь і навичок, а й досвіду емоційно-ціннісного ставлення до дійсності" [1: 98].

Дослідження шляхів застосування компетентнісного підходу в освіті проводилися як вітчизняними (О. Заболоцька, О. Овчарук, О. Пометун, Г. Терещук та ін.), так і зарубіжними (Д. Бріджес, Р. Ворхіс, I. Зимня, Р. Харріс, Г. Гасрі, Б. Гобарт та ін.) науковцями. Різноманітним аспектам вивчення сутності комунікативної компетентності, а також проблемам, пов'язаним із формуванням цієї компетентності, присвячено праці численних авторів. Зокрема, здійснювалися теоретичні дослідження цього поняття (Ю. Габермас, Д. Гаймс, І. Потюк, С. Уільсон), вивчалися особливості формування соціокультурної та міжкультурної комунікативної компетентності (Т. Колодько, О. Кричківська, В. Топалова); проблемам формування професійної комунікативної компетентності педагога присвячено праці І. Когут, Л. Козак, Г. Кошонько; шляхи формування іншомовної професійної комунікативної компетентності досліджували Н. Костенко, Н. Микитенко, Л. Морська та ін. Однак, окремих досліджень проблем формування академічної комунікативної компетентності студентів у вітчизняній педагогічній науці не здійснювалось. На нашу думку, ці питання сьогодні вимагають більшої уваги, що зумовлює мету даної праці - опираючись на прогресивний зарубіжний досвід, схарактеризувати сучасний стан академічної комунікативної підготовки майбутніх фахівців крізь призму компетентнісного підходу. Мета дослідження визначає його завдання: 1) з'ясувати педагогічну сутність поняття "академічна комунікативна компетентність", 2) виокремити іiі основні компоненти, 3) окреслити перспективи застосування компетентнісного підходу до академічної комунікативної підготовки фахівців природничої галузі.

Розмежування ключових понять компетентнісного підходу "компетентність" і "компетенція" стало предметом багатьох наукових розвідок (О. Пометун, С. Сисоєва, А. Хуторський та ін.). Окремі науковці розглядають компетенцію як певну норму освітньої підготовки, а компетентність як сформовану якість особистості. Такий підхід до інтерпретації даних понять більш розгорнуто представлено у праці С. Сисоєвої "Новий закон України "Про вищу освіту": дискусійні аспекти наукового тезаурусу", де вона стверджує, що "компетенція - це визначена норма стосовно неперервної освіти, яка задається освітніми стандартами і використовується для формування вимог до результатів навчання", а "компетентність - це інтегрована особистісна якість людини (iі капітал), що формується на етапі навчання, остаточно оформлюється і розвивається у процесі практичної діяльності та забезпечує компетентний підхід до 
вирішення професійних завдань. Компетентність $є$ оцінною характеристикою особи. Компетентності особи є ії особистісним капіталом і результатом навчання у різних формах формальної, неформальної та інформальної освіти" [2: 266]. Нам також імпонує визначення терміну "компетенція", яке дає О. Заболоцька: "компетенція - це інтегрована особистісно-діяльнісна категорія, яка формується під час навчання в результаті поєднання початкового особистого досвіду, знань, способів діяльності, вмінь, навичок, особистісних цінностей та здатності їх застосування в процесі продуктивної діяльності стосовно кола предметів та процесів певної галузі людської діяльності" [3: 64]. Така дефініція компетенції корелює із трактуванням цього поняття групою американських учених, які досліджували можливості впровадження освітніх ініціатив, базованих на застосуванні компетентнісного підходу до навчання, у ВНЗ США в рамках проекту ініційованого Департаментом освіти США. Рис. 1 ілюструє схему ієрархії навчальних здобутків студентів на рівні вищої освіти, представлену у звіті про результати виконання згаданого проекту.

На першому рівні ієрархії знаходяться особистісні характеристики студента, які складають основу його навчально-пізнавальних можливостей і визначають напрями і темпи розвитку індивіда. Другий рівень включає знання, уміння і навички, які формуються у процесі навчання. Третій рівень складають компетенції, що є результатом інтегрованого навчального досвіду, у процесі якого знання, уміння та навички взаємодіють, формуючи "вузли", необхідні для розв'язання тих чи інших задач. Комбінація компетенцій проявляється у реальній здатності студента до виконання завдань. На найвищий щабель піраміди автори схеми ставлять демонстрацію студентом такої здатності, що є результатом активації компетенцій [4: 8].

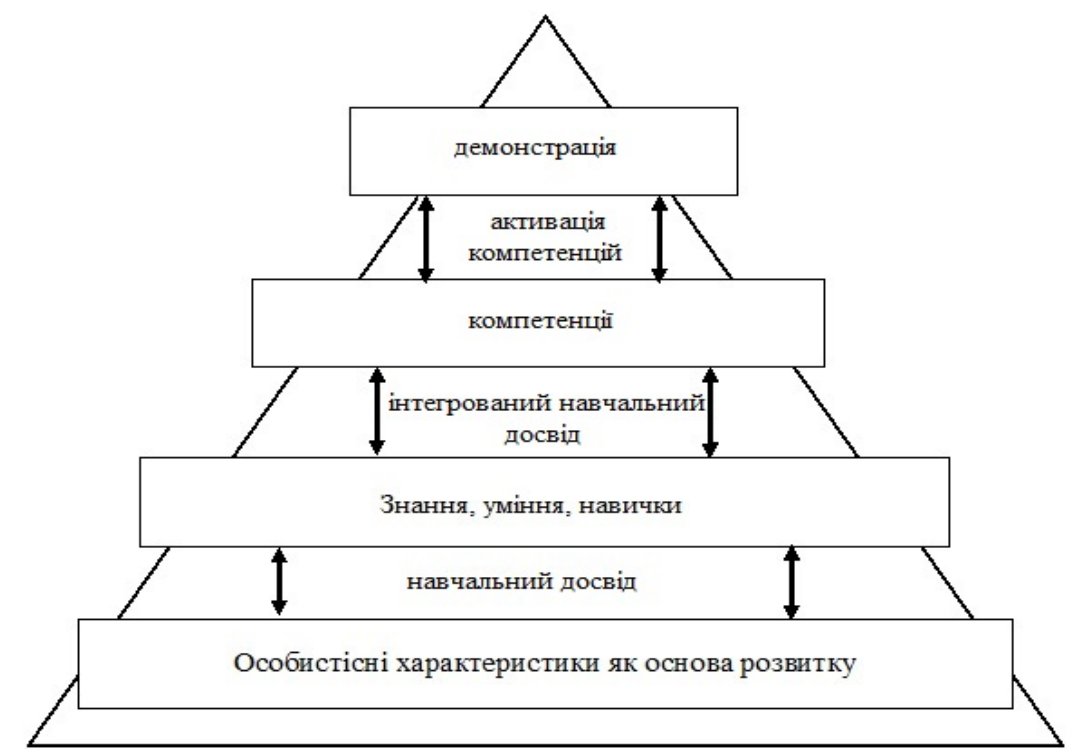

Рис. 1. Модель ісрархї навчальних здобутків студентів Р. Ворхіса та Е. Джсонса

Попри певні розбіжності в інтерпретації понять компетенції та компетентності, дослідники погоджуються, що термін "компетентність" є ширшим і в опозиції до терміну "компетенція" виконує функцію гіпероніма, тобто компетентність інтегрує у собі низку компетенцій.

У контексті цього дослідження нам близьке трактування даних понять, яке пропонує Н. Микитенко. На їі думку, компетенція - це "сукупність взаємопов’язаних знань, вмінь, навичок, способів діяльності, ставлення, що висуваються стосовно певного кола предметів і процесів, є необхідними для якісної продуктивної діяльності по відношенню до цих предметів та процесів, впливають на професійну діяльність, роль чи відповідальність". Поняття "компетентність" дослідниця трактує як "володіння людиною відповідною компетенцією, а також іiі досвід, особисте емоційно-ціннісне ставлення до предмета діяльності, до складових компетентності" [5: 33].

Аналізуючи досвід різних країн щодо реалізації компетентнісного підходу до змісту освіти, О. Пометун простежує спільні тенденції у спробах розробити певну систему компетентностей на різних рівнях змісту. Така система включає: а) надпредметні (базові, ключові, транс) компетентності, які формуються упродовж засвоєння усього змісту освіти; б) загальнопредметні компетентності, пов'язані із завданнями та змістом окремих галузей знань; в) спецііально-предметні компетентності, які набуваються у процесі вивчення конкретного предмета на певному етапі навчання [6:21]. Комунікативну компетентність зазвичай відносять до групи ключових компетентностей [5: 34]. 
Серед численних визначень комунікативної компетентності одним із найбільш загальних $\epsilon$ визначення І. Потюк, яка, опираючись на "Словник-довідник з української лінгводидактики", розглядає комунікативну компетентність як "здатність користуватися мовою залежно від ситуації, особливу якість мовленнєвої особистості, набуту у процесі спілкування або спеціально організованого навчання" [7: 132]. Існує багато підходів до визначення структури комунікативної компетентності. Ми, беручи до уваги праці Д. Гаймса, М. Кенейла та М. Свейн, схильні розглядати структуру комунікативної компетентності як поєднання таких компетенцій:

1) лінгвістичної (мовної та мовленнєвої), що включає знання про граматичну, лексичну, синтаксичну, фонетичну, орфоепічну, орфографічну та інші системи мови, а також уміння використовувати мовні засоби для сприйняття (читання, слухання) та створення (говоріння, письмо) висловлювань;

2) соичіокультурної, яка проявляється в умінні правильно інтерпретувати соціальний контекст комунікації та характер взаємовідносин комунікантів; знанні та умінні застосовувати норми вербальної та невербальної поведінки, відповідно до ситуації;

3) дискурсної, яка передбачає вміння застосовувати адекватні мовні моделі для реалізації відповідних мовленнєвих функцій, а також здатність структурувати мовлення та керувати ним за допомогою тематичної організації, зв'язності, стилю, реєстру, риторичної ефективності;

4) стратегічної, яка включає вміння використовувати належні стратегії для розв'язання комунікативних задач, а також бажання спілкуватись і розуміти інших [7: 130-131; 8: 32-34].

Розглядаючи професійну комунікативну компетентність, О. Низовець характеризує це поняття як "здатність встановлювати і підтримувати необхідні контакти 3 іншими людьми в рамках професійної діяльності ..., яка $€$ інтегральним, відносно стабільним, цілісним утворенням, що проявляється в індивідуально-психологічних властивостях та особливостях спілкування, включає сукупність знань, досвіду, якостей, здібностей особистості, які дають змогу ефективно виконувати професійні комунікативні функції" [9: 8]. Академічна комунікативна компетентність (АКК) тісно пов'язана 3 професійною комунікативною компетентністю. Поєднання цих компонентів особливо важливе у формуванні комплексу професійних компетентностей майбутнього фахівця природничої галузі, потенційного науковця.

У вітчизняній науково-педагогічній літературі не знаходимо дефініції поняття "академічна комунікативна компетентність". Тому, опираючись на наше визначення академічної комунікації як соціально-риторичної взаємодії між індивідами в межах дискурсної академічної спільноти університету, що "спрямована на досягнення цілей, пов'язаних із освітньою та науково-дослідницькою діяльністю" [10: 13] та численні визначення педагогічної категорії "комунікативна компетентність", пропонуємо розглядати академічну комунікативну компетентність як інтегральну якість особистості учасника академічної дискурсної спільноти, з допомогою якої він може провадити ефективну навчальну, науково-дослідницьку та науково-професійну діяльність, здійснювати обмін інформацією, думками, судженнями та міркуваннями з іншими членами академічного середовища та виконувати відповідні ролі і функції у ц̧ьому середовищі.

На нашу думку, АКК інтегрує компоненти ключових, галузевих та спеціально-предметних компетентностей, що включають наступні компетенції: навчальну, дослідницьку, інформаційну, рефлексійну, мовну, мовленнєву, дискурсну (риторичну), соціокультурну та стратегічну. Пропонуємо систематизувати названі компетенції, об’єднавши їх у 3 групи:

- когнітивні - пов'язані із здійсненням навчальної та дослідницької діяльності, рефлексії, самооцінки;

- $\quad$ власне-комунікативні - такі, що включають знання уміння і навички, пов'язані із використанням засобів мови і мовлення для досягнення комунікативних цілей;

- $\quad$ aдаптивні - такі, що передбачають здатність індивіда до соціалізації у відповідні комунікативнодіяльнісні спільноти, уміння пристосовуватись до нових соціокультурних умов (див. Табл. 1).

Зведена таблиця компонентів академічної комунікативної компетентності

\begin{tabular}{|c|l|l|l|}
\hline $\begin{array}{c}\text { групи } \\
\text { компетенцій }\end{array}$ & компетенції & \multicolumn{1}{|c|}{ знання } & \multicolumn{1}{|c|}{ уміння та навички } \\
\hline когнітивні & $\begin{array}{l}\text { навчальна } \\
\text { дослідницька } \\
\text { інформаційна } \\
\text { рефлексійна }\end{array}$ & $\begin{array}{l}\text { предметні; } \\
\text { мета мов; } \\
\text { про процеси } \\
\text { навчально-пізнавальної } \\
\text { та комунікативної } \\
\text { діяльності; } \\
\text { про дисциплінарні } \\
\text { способи пізнання }\end{array}$ & $\begin{array}{l}\text { здійснювати аналіз, синтез, порівняння, } \\
\text { класифікацію, систематизацію інформації; } \\
\text { критичн мислити; } \\
\text { діяльнісні контексти; } \\
\text { оцінювати та організовувати власну } \\
\text { навчально-пізнавальну та комунікативну } \\
\text { діяльність; }\end{array}$ \\
\hline
\end{tabular}




\begin{tabular}{|c|c|c|c|}
\hline & & & $\begin{array}{l}\text { застосовувати сучасні інформаційно- } \\
\text { комунікаційні технології для здійснення } \\
\text { навчально-комунікативної та науково- } \\
\text { дослідницької діяльності }\end{array}$ \\
\hline $\begin{array}{l}\text { власне- } \\
\text { комуніка- } \\
\text { тивні }\end{array}$ & $\begin{array}{l}\text { мовна } \\
\text { мовленнєва } \\
\text { дискурсна }\end{array}$ & $\begin{array}{l}\text { лексики (у т. ч. фахової } \\
\text { термінології), } \\
\text { граматики, фонетики, } \\
\text { орфографії, орфоепії, } \\
\text { синтаксису; } \\
\text { про жанри науково- } \\
\text { академічної } \\
\text { комунікації; } \\
\text { лінгво-стилістичних } \\
\text { норм науково- } \\
\text { академічного дискурсу }\end{array}$ & \begin{tabular}{l}
\multicolumn{1}{c}{ використовувати мовні засоби для } \\
ефективного обміну інформацією у \\
процесі слухання, читання, говоріння та \\
письма; \\
розпізнавати риторичні інтенції \\
комунікаторів; \\
застосовувати ефективні риторичні \\
стратегії впливу на адресата; \\
розпізнавати різні типи аудиторії; \\
адаптувати власні комунікативні стратегії \\
до потреб аудиторії
\end{tabular} \\
\hline адаптивні & $\begin{array}{l}\text { соціо- } \\
\text { культурна } \\
\text { стратегічна }\end{array}$ & $\begin{array}{l}\text { знання про } \\
\text { соціокультурні норми } \\
\text { лінгвістичної та екстра- } \\
\text { лінгвістичної } \\
\text { поведінки у } \\
\text { академічному } \\
\text { середовищі, їх } \\
\text { відповідність до } \\
\text { статусу та ролі } \\
\text { комунікантів }\end{array}$ & $\begin{array}{l}\text { застосовувати вербальні та невербальні } \\
\text { засоби комунікації для досягнення } \\
\text { власних цілей відповідно до культурних } \\
\text { та соціальних стандартів академічної } \\
\text { дискурсної спільноти; } \\
\text { розпізнавати перешкоди для ефективної } \\
\text { комунікації та усувати їх }\end{array}$ \\
\hline
\end{tabular}

Здійснений нами аналіз педагогічної системи інтегрованої дисциплінарно-академічної комунікативної підготовки, яка функціонує сьогодні у більшості університетів США [10], показав, що компетентнісний підхід є провідним до формування змісту навчання майбутніх фахівців природничої галузі. В рамках згаданої педагогічної системи формування АКК студентів відбувається поетапно та неперервно впродовж усіх років навчання. На базовому етапі комунікативної підготовки розвиваються ключові комунікативні компетенції, які можна переносити у різні сфери навчального, галузевого та фахового застосування. Другий етап АКП присвячений формуванню загальнопредметних комунікативних компетенцій, а також засвоєнню знань, умінь і навичок комунікації у різножанровому навчальноакадемічному середовищі. На старших курсах бакалаврату та подальших рівнях вищої освіти розвиток комунікативної компетентності відбувається у тісному зв'язку із формуванням вузькопрофесійних компетентностей фахівця [10: 14].

Висновки. У ході проведеного дослідження академічну комунікативну компетентність визначено як інтегральну якість особистості члена академічної спільноти, що дає йому можливість здійснювати навчальну, науково-дослідницьку та науково-професійну діяльність у академічному середовищі. АКК інтегрує компоненти ключових, галузевих та спеціально-предметних компетентностей і вміщує три групи компетенцій: когнітивні компетенції (навчальну, дослідницьку, інформаційну, рефлексійну); власне-комунікативні компетенції (мовну, мовленнєву, дискурсну); адаптивні компетенції (соціокультурну та стратегічну). Вивчення зарубіжного досвіду показало високу ефективність використання компетентнісного підходу до дисциплінарно-академічної комунікативної підготовки студентів природничих спеціальностей, особливо на етапах цілепокладання, змістового наповнення програм такої підготовки та контролю знань. Запозичення прогресивного досвіду високорозвинених систем вищої освіти, таких як американська, щодо застосування компетентнісного підходу в навчанні може суттєво покращити якість підготовки майбутніх фахівців сфери природничих наук у вітчизняних BH3.

\section{СПИСОК ВИКОРИСТАНИХ ДЖЕРЕЛ ТА ЛІТЕРАТУРИ}

1. Лозова В. І. Стратегічні питання сучасної дидактики / В. І. Лозова // Розвиток педагогічної і психологічної наук в Україні 1992-2002 : [збірник наукових праць до 10-річчя АПН України] / гол. ред. В. Г. Кремень ; АПН України. - Харків : ОВС, 2002. - Ч. 1. - 640с. - С. 95-109 .

2. Сисоєва С. О. Новий Закон України "Про вищу освіту" : дискусійні аспекти наукового тезаурусу [Електронний ресурс] / С. О. Сисоєва // Освітологічний дискурс : ел. фахове видання КУ імені Бориса Грінченка. - 2015. - № 3 (11). - С. 261-269. - Режим доступу: 20.05.2016: http://od.kubg.edu.ua/index.php/journal/article/view/288/234\#.VevsUfntmko. - Загол. з екрана. - Мова укр. 
3. Заболоцька О. С. Компетентнісний підхід як освітня інновація : порівняльний аналіз / О. С. Заболоцька // Вісник Житомирського державного університету. - 2008. - Вип. 40. - Серія : Педагогічні науки. - С. 63-68.

4. Defining and Assessing Learning : Exploring Competency-Based Initiatives, NCES 2002-159 [Електронний pecypc]. - Report of the National Postsecondary Education Cooperative Working Group on Competency-Based Initiatives in Postsecondary Education [E. A. Jones, R. A. Voorhees, K. Paulson]. - Washington, DC : NPEC, 2002. - 175 р.. - Режим доступу : 10.05.2016 : http://nces.ed.gov/pubs2002/2002159.pdf. - Загол. з екрана. - Мова англ.

5. Микитенко Н. О. Технологія формування іншомовної професійної компетентності майбутніх фахівців природничого профілю : [монографія] / Н. О. Микитенко. - Тернопіль : ТНПУ, 2011. - 411 с.

6. Пометун О. І. Теорія та практика послідовної реалізації компетентнісного підходу в досвіді зарубіжних країн / О.І.Пометун // Компетентнісний підхід у сучасній освіті : Світовий досвід та українські перспективи : (Бібліотека з освітньої політики) : [колективна монографія] / Під заг. ред. О. В. Овчарук. - К. : "K.I.C.", 2004. - 112 c. - C. 15-24.

7. Потюк I. Комунікативна компетенція як невід’ємна складова навчально-виховного процесу / I. Потюк // Молодь і ринок. - № 1 (84). - 2012. - С. 128-132.

8. Canale M. Theoretical Framework for Communicative Competence / M. Canale, M. Swain // The Construct Validation of Test of Communicative Competence / [Eds. A. Palmer, P. Groot, G. Trosper]. - Washington, DC : TESOL, 1981. - 165 p. - P. 31-36.

9. Низовець О. А. Особистісні детермінанти розвитку комунікативної компетентності майбутніх психологів : автореф. дис. ... канд. психол. наук : 19.00.07 / Олена Анатоліївна Низовець. - К., 2011. - 23 с.

10. Козолуп М. С. Технології підготовки майбутніх фахівців природничих спеціальностей до академічної комунікації в університетах США : автореф. дис. ... канд. пед. наук : 13.00 .04 / Марія Степанівна Козолуп. Тернопіль, 2017. -20 c.

\section{REFERENCES (TRANSLATED \& TRANSLITERATED)}

1. Lozova V. I. Stratehichni pytannia suchasnoi dydaktyky [Strategic Issues of Modern Didactics] / V. I. Lozova // Rozvytok pedahohichnoii psykholohichnoi nauky v Ukraini 1992-2002 [The Development of Pedagogical Science in Ukraine] : [zbirnyk naukovykh prats' do 10-richchia APN Ukrainy] / hol. red. V. H. Kremen'; APN Ukrainy. Kharkiv : OVS, 2002. - Ch. 1. -640 s. - S. 95-109.

2. Sysoieva S. O. Novyi Zakon Ukrainy "Pro vyshchu osvitu" : dyskusiini aspekty naukovoho tezaurusu [The New Law of Ukraine "On Higher Education": Discursive Aspects of Scientific Thesaurus] [Elektronnyi resurs] / S. O. Sysoieva // Osvitolohichnyi dyskurs [Educational Discourse] : el. fakhove vydannia KU imeni Borysa Hrinchenka. - 2015. - № 3 (11). - S. 261-269. - Rezhym dostupu: 20.05.2016: http://od.kubg.edu.ua/index.php/journal/article/view/288/234\#.VevsUfntmko. - Zahol. z ekrana. - Mova ukr.

3. Zabolotska O.S. Kompetentnisnyi pidkhid yak osvitnia innovatsiia : porivnial'nyi analiz [Competency-Based Approach as an Educational Innovation : Comparative Analysis] / O. S. Zabolotska // Visnyk Zhytomyrs'koho derzhavnoho universytetu [Zhytomyr Ivan Franko State University Journal]. - 2008. - Vyp. 40. - Seriia : Pedahohichni nauky. - S. 63-68.

4. Defining and Assessing Learning : Exploring Competency-Based Initiatives, NCES 2002-159 [Elektronnyi resurs]. - Report of the National Postsecondary Education Cooperative Working Group on Competency-Based Initiatives in Postsecondary Education [E. A. Jones, R. A. Voorhees, K. Paulson]. - Washington, DC : NPEC, 2002. - 175 p.. Rezhym dostupu : 10.05.2016 : http://nces.ed.gov/pubs2002/2002159.pdf. - Zagol. z ekrana. - Mova angl.

5. Mykytenko N. O. Tekhnolohiia formuvannia inshomovnoi profesiinoi kompetentnosti maibutnikh fakhivtsiv pryrodnychoho profiliu [Technology of Foreign Language Professional Competency Development in Science Majors] : [monohrafiia] / N. O. Mykytenko. - Ternopil' : TNPU, 2011. - $411 \mathrm{~s}$.

6. Pometun O. I. Teoriia ta praktyka poslidovnoi realizatsii kompetentnisnoho pidkhodu v dosvidi zarubizhnykh krain [The Theory and Practice of Consistent Implementation of the Competency-Based Approach in Foreign Experience] / O. I. Pometun // Kompetentnisnyi pidkhid u suchasnii osviti: Svitovyi dosvid ta ukrains'ki perspektyvy [Competency-Based Approach in Modern Education: International Experience and Ukrainian Prospects] : (Biblioteka z osvitnoi polityky) : [kolektyvna monohrafiia] / Pid zah. red. O. V. Ovcharuk. - K. : "K.I.S.", 2004. 112 s. - S. $15-24$.

7. Potiuk I. Komunikatyvna kompetentsiia yak nevidiemna skladova navchal'no-vykhovnoho protsesu [Communicative Competence as an Integral Part of Educational Process] / I. Potiuk // Molod' i rynok [Youth and Market]. - № 1 (84). - 2012. - S. 128-132.

8. Canale M. Theoretical Framework for Communicative Competence / M. Canale, M. Swain // The Construct Validation of Test of Communicative Competence / [Eds. A. Palmer, P. Groot, G. Trosper]. - Washington, DC : TESOL, 1981. - 165 p. - P. 31-36.

9. Nyzovets O. A. Osobystisni determinanty rozvytku komunikatyvnoi kompetentnosti maibutnikh psykholohiv [Personality Determinants of Future Psychologists' Communicative Competence Development] : avtoref. dys. ... kand. psykhol. nauk : 19.00.07 / Olena Anatoliivna Nyzovets. - K., 2011. - 23 s.

10. Kozolup M. S. Tekhnolohii pidhotovky maibutnikh fakhivtsiv pryrodnychykh spetsial'nostei do akademichnoi komunikatsii v universytetakh SShA [Educational Technologies of Science Majors Preparation for Academic Communication in the Universities of the United States] : avtoref. dys. ... kand. ped. nauk : 13.00.04/ Mariia Stepanivna Kozolup. - Ternopil', 2017. - 20 s. 


\section{Козолуп М. С. Академическая коммуникативная подготовка студентов в вузах: компетентностный подход.}

Статья посвящена изучению путей применения компетентностного подхода к академической коммуникативной подготовке будущих специалистов естественной отрасли в вузах. В ходе исследования выяснено сущность и предложено определение понятия "академическая коммуникативная компетентность". Рассмотрена структура данной компетентности, интегрируюшей компоненть ключевых, отраслевых и специально-предметных компетентностей и включающей три группы компетенций: когнитивные, собственно коммуникативные и адаптивнье. Обоснована эффективность использования компетентностного подхода к дисциплинарно-академической коммуникативной подготовке студентов естественных специальностей на основании изучения опыта американской системы высшего образования.

Ключевые слова: компетентностный подход, компетенция, компетентность, коммуникативная компетентность, академическая коммуникативная компетентность.

\section{Kozolup M. S. Academic Communication Instruction of University Students: Competency-Based Approach.}

The research focuses on theoretical and practical issues of applying competency-based approach to teaching communication to science majors. A special emphasis is placed on developing the ability of the incoming members of the academic discourse community to function efficiently in disciplinary academic environments by means of improving their sociolinguistic skills. Research methods of analysis, synthesis, description and classification have been used to define the key terms of the study, namely "competence", "competency", "communicative competency" and "academic communicative competency" and present the structure of academic communicative competency. The latter comprises three major groups of competences: cognitive (which further includes learning, research, informational and reflective competences), proper communicative (linguistic,

language and discursive competences) and adaptive (sociocultural and strategic competences). The analysis of American pedagogical literature as well as the US university programs has revealed that communication education takes place throughout the whole period of study at both undergraduate and graduate levels and can be divided into three main stages: 1) the development of general academic communicative competences; 2) the development of field-related communicative competences; 3) the development of disciplinary and research specific communicative competences. The study results demonstrate the effectiveness of the competency-based approach to teaching communication in the US universities and colleges, especially in program development and student assessment. This suggests that an appropriate adaptation of the American educational experience to Ukrainian conditions may facilitate the process of the communicative competency formation in future professionals and scientists.

Key words: competency-based approach, competence, competency, communicative competency, academic communicative competency. 